\title{
Analisis Tingkat Berpikir Siswa Berdasarkan Teori Van Hiele Materi Segi Empat dan Segitiga Ditinjau dari Gaya Kognitif
}

\author{
Nurhaolida $^{1, \text { a) }}$, Laila Hayati ${ }^{2, \text { b) }}$, Nourma Pramestie Wulandari ${ }^{3, \text { c) }}$ Syahrul Azmi ${ }^{4, \text { d) }}$ \\ ${ }^{1234}$ Universitas Mataram, Mataram \\ Email penulis: ${ }^{\text {a)}}$ nurhaolida98@ gmail.com, b) lailahayati.fkip@unram.ac.id, ${ }^{\mathrm{c})}$ nourmapw@unram.ac.id, \\ ${ }^{c}$ syahrulazmi.fkip@gmail.com
}

\begin{abstract}
This study aims to describe students' thinking levels based on Van Hiele's theory on quadrilaterals and triangles material in terms of reflective and impulsive cognitive styles. The research method used is descriptive qualitative. The subjects in this study were students of class VIII H SMP Negeri 1 Wanasaba. The instruments used are cognitive style tests, geometry tests, and interviews. The results showed that the cognitive style of students in class VIII H of SMP Negeri 1 Wanasaba was generally dominated by students with reflective and impulsive cognitive styles, $71.9 \%$ greater than students with fast accurate and slow inaccurate cognitive styles, namely $28.1 \%$. Students with reflective cognitive style are generally at the analysis level (level 1). Reflektive students are able to identify the shapes of quadrilaterals and triangles, are able to determine the names of a quadrilateral and triangular shapes, are able to determine the properties and similarities of the properties. Students with impulsive cognitive style are generally at the visualization level (level 0). Impulsive student at this level are able to identify rectangular and triangular and are able to determine the names of flat shapes correctly but not yet complete.
\end{abstract}

Keywords: cognitive styles, quadrilaterals, triangles, Van Hiele theory, student's thingking levels

\begin{abstract}
Abstrak
Tujuan dari penelitian ini adalah untuk mendeskripsikan tingkat berpikir siswa berdasarkan teori Van Hiele pada materi segiempat dan segitiga ditinjau dari gaya kognitif reflektif dan impulsif. Metode penelitian yang digunakan adalah deskriptif kualitatif. Subjek dalam penelitian ini adalah siswa kelas VIII H SMP Negeri 1 Wanasaba. Adapun instrumen yang digunakan berupa tes gaya kognitif, tes geometri, dan wawancara. Hasil penelitian menunjukkan bahwa gaya kognitif siswa kelas VIII H secara umum didominasi oleh siswa yang bergaya kognitif reflektif dan impulsif 71,9\% lebih besar jika dibandingkan dengan siswa bergaya kognitif fast accurate dan slow inaccurate yaitu $28,1 \%$. Siswa dengan gaya kognitif reflektif secara umum berada pada tingkat analisis (tingkat 1). Siswa reflektif sudah mampu mengidentifikasi bentuk bangun segiempat dan segitiga, mampu menentukan nama-nama suatu bangun dan, mampu menentukan sifat-sifat dan kesamaan sifat beberapa bangun segiempat. Siswa dengan gaya kognitif impulsif secara umum berada pada tingkat visualisasi (tingkat 0). Siswa impulsif sudah mampu mengidentifikasi bentuk bangun segiempat dan segitiga dan mampu menentukan nama-nama suatu bangun datar dengan benar namun belum lengkap.
\end{abstract}

Kata kunci: gaya kognitif, segiempat, segitiga, teori Van Hiele, tingkat berpikir siswa

Copyright (c) 2022 Nurhaolida, Hayati, Wulandari, Azmi

$\triangle$ Corresponding author:

Email Address: nurhaolida98@gmail.com

Received 20 Januari 2022, Accepted 23 Februari 2022, Published 24 Februari 2022

https://doi.org/10.21009/jrpmj.v4i1.23024

\section{PENDAHULUAN}

Geometri merupakan cabang matematika yang diajarkan pada setiap jenjang pendidikan, baik pada jenjang sekolah dasar hingga perguruan tinggi. Geometri memegang peranan penting dalam mempelajari konsep lain dalam pembelajaran matematika (Van de Walle, 2001:309). Pada dasarnya, geometri mempunyai peluang yang lebih besar untuk dipahami siswa dibandingkan dengan cabang 
matematika yang lain. Hal ini dikarenakan ide-ide geometri sudah dikenal oleh siswa sejak sebelum mereka masuk sekolah, misalnya garis, bidang, dan ruang (Junaedi, 2017). Meskipun demikian, bukti di lapangan menunjukkan bahwa hasil belajar geometri masih rendah. Berikut disajikan Tabel 1 data Pusat Penilaian Pendidikan (Puspendik) Kementerian Pendidikan dan Kebudayaan (Kemendikbud) pada Ujian Nasional tahun 2019.

\begin{tabular}{clc}
\hline No & \multicolumn{1}{c}{ Materi yang Diuji } & Nasional \\
\hline 1 & Bilangan & 39,71 \\
2 & Aljabar & 51,24 \\
3 & Geometri dan pengukuran & 42,27 \\
4 & Statistika dan Peluang & 55,60 \\
\hline
\end{tabular}

Tabel 1. Persentase Siswa yang Menjawab Benar Tahun Pelajaran 2018/2019

Berdasarkan Tabel 1 di atas, persentase siswa yang menjawab benar pada materi geometri menempati posisi kedua terbawah setelah materi bilangan yaitu 42,27. Hal ini menunjukkan bahwa siswa masih kesulitan dalam menjawab soal-soal materi geometri. Kesulitan dalam geometri juga dialami oleh siswa SMP Negeri 1 Wanasaba. Berdasarkan hasil wawancara dengan guru mata pelajaran matematika, diketahui bahwa kebanyakan siswa masih kesulitan dalam mempelajari sifatsifat geometri khususnya segiempat dan segitiga, dimana materi tersebut harusnya sudah dipelajari ketika Sekolah Dasar. Selama ini, guru juga tidak pernah mempertimbangkan tingkat berpikir geometri siswa, padahal dalam menyelesaikan masalah geometri sangat penting mengetahui tingkat berpikir siswa. Menurut Petrus, Karmila, \& Riyadi (2017) tidak dipungkiri ada perbedaan proses berpikir antara siswa dan guru sehingga siswa tidak mampu mengikuti apa yang diajarkan oleh guru.

Teori yang menjelaskan mengenai tingkat berpikir siswa dalam mempelajari geometri yaitu teori Van Hiele. Teori Van Hiele menyatakan bahwa siswa tidak dapat naik ke tingkat yang lebih tinggi tanpa melewati tingkat yang lebih rendah (Intan, Sahara, \& Nurfauziah, 2021). Adapun tingkat berpikir geometri siswa secara berurutan melalui 5 tahap yaitu, tingkat 0 (visualisasi), tingkat 1 (analisis), tingkat 2 (deduksi informal), tingkat 3 (deduksi), dan tingkat 4 (rigor) (Van de Walle, 2001:309). Setiap siswa tentu memiliki jawaban yang berbeda dalam menyelesaikan soal geometri. Perbedaan hasil jawaban siswa tergantung informasi yang diserap dan diolah siswa selama pembelajaran. Hal ini sejalan dengan Desmita (2009:145) yang memaparkan bahwa, setiap siswa akan berbeda dalam menghadapi tugas, tetapi perbedaan ini tidak mencerminkan tingkat intelegensinya. Perbedaan yang terjadi hanya sebagai ciri khas yang dimiliki siswa untuk memproses dan mengorganisasi informasi dan sebagai bentuk respon terhadap lingkungan belajarnya. Ciri khas siswa dalam menyusun dan mengolah informasi dinamakan sebagai gaya kognitif (Mahfiroh dkk, 2021). Perbedaan gaya kognitif inilah yang memungkinkan siswa berbeda dalam cara memahami materi dan menyelesaikan permasalahan yang terdapat pada soal geometri khususnya materi segiempat dan segitiga. 
Menurut Kagan (1965) ada dua penggolongan gaya kognitif yaitu gaya kognitif reflektif dan gaya kognitif impulsif. Siswa yang bergaya kognitif reflektif memiliki karakteristik lambat dalam menjawab masalah, tetapi cermat atau teliti, sehingga jawaban cenderung benar. Siswa reflektif merespon masalah melalui pemeriksaan kritis dengan mempertimbangkan solusi alternatif dan mempunyai konsentrasi yang tinggi saat belajar. Sedangkan siswa yang bergaya kognitif impulsif memiliki karakteristik cepat dalam menjawab masalah, tetapi kurang cermat, sehingga jawaban cenderung salah. siswa impulsif merespon masalah dengan apa yang terlintas di pikiran dan kurang konsentrasi saat pembelajaran di dalam kelas.

Perbedaan gaya kognitif baik gaya kognitif reflektif maupun gaya kognitif impulsif yang menyebabkan tingkat berpikir siswa berbeda-beda khususnya dalam menyelesaikan soal geometri materi segiempat dan segitiga (Ilhamuddin dkk, 2021). Sehingga, perlu dilakukan penelitian mengenai tingkat berpikir siswa berdasarkan teori Van Hiele jika dilihat dari gaya kognitif reflektif dan gaya kognitif impulsif. Berdasarkan paparan tersebut, penelitian mengenai tingkat berpikir siswa menjadi bagian yang menarik untuk ditelusuri terlebih penelitian ini belum pernah dilakukan di SMP Negeri 1 Wanasaba. Adapun tujuan penelitian yang akan dilakukan yaitu untuk mendeskripsikan tingkat berpikir siswa berdasarkan teori Van Hiele baik siswa yang bergaya kognitif reflektif maupun impulsif. Informasi ini akan memberikan pengetahuan baru bagi guru, sehingga dapat menentukan strategi dalam mengarahkan siswa menuju tingkat berpikir yang lebih tinggi dengan harapan lebih dapat menguasai konsep dari materi segiempat dan segitiga yang telah diberikan.

\section{METODE}

Jenis penelitian yang digunakan dalam penelitian ini adalah penelitian deskriptif kualitatif yang bertujuan untuk menghasilkan data deskriptif tingkat berpikir geometri siswa reflektif maupun impulsif berupa kata-kata tertulis atau lisan (Moleong, 2014:4). Penelitian ini dilaksanakan di SMP Negeri 1 Wanasaba pada semester ganjil tahun pelajaran 2021/2022. Populasi yang digunakan adalah siswa kelas VIII dan teknik pemilihan sampel menggunakan purposive sampling. Adapun sampel yang terpilih adalah siswa kelas VIII H. Teknik pengumpulan data berupa tes Matching Familiar Figure Test (MFFT) yang dikembangkan oleh Warli (2013) untuk mengetahui gaya kognitif siswa dan tes geometri segiempat dan segitiga untuk menentukan tingkat berpikir siswa berdasarkan teori Van Hiele. Sebelum soal tes geometri diujikan terlebih dahulu dilakukan validitas isi menggunakan validitas Aiken (Aiken, 1985).

$$
V=\frac{\sum s}{n(c-1)} \text { dimana, } s=r-l_{o}
$$

Keterangan:

$V$ : Indeks Validitas Butir

$r$ : Angka yang diberikan oleh penilai 
$l_{o}$ : Angka penilaian validitas terendah (misalnya 1 )

$c$ : Angka penilaian validitas tertinggi (misalnya 5)

$n:$ Banyak Validator

Nilai indeks Aiken berkisar antara 0-1. Nilai yang diperoleh kemudian diklasifikasikan tingkat validitasnya dengan validitas minimal untuk semua item dan berapapun jumlah validator sebesar 0,60 (Saifuddin, 2020).

\begin{tabular}{cc}
\hline Indeks Validitas Aiken & Keterangan \\
\hline $\mathrm{V} \geq 0,60$ & Valid \\
$\mathrm{V}<0,60$ & Tidak Valid \\
\hline
\end{tabular}

Tabel 2. Kriteria Validitas Instrumen

Adapun teknik analisis data yang digunakan meliputi teknik analisis data Matching Familiar Figure Test (MFFT), teknik analisis data hasil tes geometri tingkat berpikir siswa berdasarkan teori Van Hiele dan teknik analisis data hasil wawancara.

\section{HASIL DAN PEMBAHASAN}

Pengelompokan gaya kognitif siswa ditentukan berdasarkan waktu pertama kali menjawab $(t)$ dan frekuensi menjawab sampai memperoleh jawaban benar $(f)$. Median waktu dan median frekuensi menjawab digunakan sebagai batas pembeda. Selanjutnya diperoleh empat kelompok siswa yaitu kelompok I siswa yang mempunyai karakteristik cepat dalam menjawab masalah dan cermat/teliti sehingga jawaban cenderung benar (fast accurate). Kelompok II siswa yang mempunyai karakteristik lambat dalam menjawab masalah dan cermat/teliti sehingga jawaban cenderung benar (reflektif). Kelompok III siswa yang mempunyai karakteristik cepat dalam menjawab masalah tetapi kurang cermat/kurang teliti sehingga jawaban cenderung salah (impulsif). Kelompok IV siswa yang mempunyai karakteristik lambat dalam menjawab masalah dan kurang cermat/kurang teliti sehingga jawaban cenderung salah (slow inaccurate). Berikut disajikan Tabel 3 pengelompokan gaya kognitif siswa kelas VIII H.

\begin{tabular}{clcc}
\hline No & Jenis Gaya Kognitif & Jumlah Siswa & Persentase \\
\hline 1 & fast accurate & 5 & $15,6 \%$ \\
2 & Reflektif & 12 & $37,5 \%$ \\
3 & Impulsif & 11 & $34,4 \%$ \\
4 & slow inaccurate & 4 & $12,5 \%$ \\
\hline
\end{tabular}

Tabel 3. Hasil Pengukuran Gaya Kognitif

Berdasarkan Tabel 3 diketahui bahwa proporsi siswa yang memiliki gaya kognitif reflektif dan impulsif mencapai $71,9 \%$ yang artinya lebih besar dibandingkan dengan siswa yang memiliki karakteristik fast accurate ataupun slow inaccurate yang hanya 28,1\%. Hasil ini sesuai dengan penelitian yang dilakukan oleh Rozencwajg \& Corroyer (2005) yaitu proporsi siswa reflektif dan 
impulsif 76,2\% lebih besar dibandingkan dengan gaya kognitif lain. Penelitian juga dilakukan oleh Azhil, Ernawati, \& Lutfianto (2017) menyatakan bahwa proporsi siswa reflektif dan impulsif $77 \%$ lebih besar dibandingkan dengan gaya kognitif fast accurate dan slow inaccurate yaitu 23\%. Lebih lanjut, penelitian yang dilakukan oleh Indah, Prayitno, Amrullah, \& Baidowi (2021) proporsi siswa reflektif dan impulsif 55\% lebih besar dibandingkan dengan gaya kognitif fast accurate dan slow inaccurate yaitu $45 \%$. Berdasarkan paparan tersebut, dalam penelitian ini hanya akan diulas lebih lanjut mengenai tingkat berpikir siswa reflektif dan impulsif.

Setelah siswa dikelompokkan berdasarkan gaya kognitif yang dimiliki, kemudian siswa diberikan tes geometri materi segiempat dan segitiga. Tes ini digunakan untuk mengetahui ketercapaian tingkat berpikir siswa berdasarkan teori Van Hiele. Berikut disajikan Gambar 1 hasil tes geometri siswa pada materi segiempat dan segitiga.

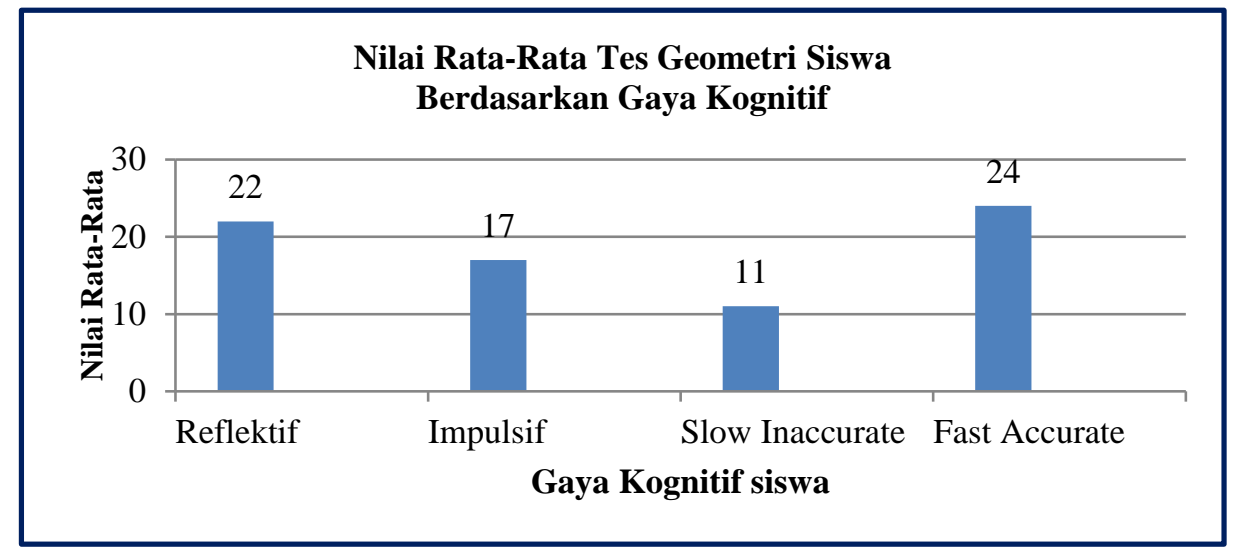

Gambar 1. Hasil Tes Geometri Siswa Berdasarkan Gaya Kognitif

Berdasarkan Gambar 1 di atas, diketahui bahwa nilai rata-rata tertinggi diperoleh siswa yang bergaya kognitif fast accurate dan nilai rata-rata terendah diperoleh siswa slow inaccurate. Adapun nilai rata-rata siswa reflektif lebih besar dibandingkan siswa impulsif. Meskipun demikian, nilai ratarata yang diperoleh siswa masih rendah. Hal ini dikarenakan nilai rata-rata siswa baik siswa reflektif, impulsif, slow inaccurate, dan fast accurate berada dibawah nilai 50\%. Nilai tersebut juga belum memenuhi KKM, mengingat KKM untuk pelajaran matematika di SMP Negeri 1 Wanasaba sebesar 70. Adapun nilai yang diperoleh siswa pada pada hasil tes geometri tidak menjadi dasar untuk menentukan tingkat berpikir geometri siswa. Pengukuran ketercapaian tingkat berpikir geometri siswa didasarkan pada kemampuan siswa dalam menjawab soal dari masing-masing level. Menurut Usiskin (1982:23) jika 60\% dari soal untuk suatu tingkat berpikir Van Hiele terjawab dengan benar artinya siswa berhasil melewati tingkatan tersebut. Oleh karena itu, tinggi rendahnya perolehan nilai tes geometri tersebut belum dapat menentukan tinggi rendahnya tingkat berpikir Van Hiele yang dicapai siswa. Berikut disajikan Tabel 4 tingkat berpikir Van Hiele yang mampu dicapai siswa kelas VIII H SMP Negeri 1 Wanasaba. 


\begin{tabular}{cccc}
\hline Siswa & Tingkat Berpikir Van Hiele & Jumlah Siswa & Persentase siswa \\
\hline Reflektif & Tingkat Analisis & 12 siswa & $100 \%$ \\
Impulsif & Tingkat Visualisasi & 7 siswa & $64 \%$ \\
Slow & Tingkat Analisis & 4 siswa & $36 \%$ \\
Inaccurate & Tingkat Pravisualisai & 2 siswa & $50 \%$ \\
Fast Accurate & Tingkat Visualisasi & 2 siswa & $50 \%$ \\
\hline
\end{tabular}

Tabel 4.1 Tingkat Berpikir Geometri Van Hiele

Berdasarkan Tabel 4 dapat dilihat hasil tes geometri siswa menunjukkan bahwa siswa kelas VIII H SMP Negeri 1 Wanasaba memiliki tingkat berpikir geometri Van Hiele yang berbeda-beda. Tingkat berpikir siswa reflektif berada pada tingkat analisis (tingkat 1) sedangkan siswa impulsif berada pada tingkat visualisasi (tingkat 0) sebanyak 7 siswa atau 64\% dan tingkat analisis (tingkat 1) sebanyak $36 \%$ atau 4 orang siswa. Hasil ini sejalan dengan penelitian yang dilakukan oleh Aditya \& Musa (2016); Anwar (2019); dan Sa'o, Naja, \& Mei (2020) pada siswa SMP menunjukkan bahwa tingkat berpikir geometri siswa berada pada tingkat 0 (visualisasi) dan tingkat 1 (analisis).

\section{Analisis Tingkat Berpikir Siswa dengan Gaya Kognitif Reflektif}

Pada tahap visualisasi (tingkat 0) siswa reflektif sudah mampu mengidentifikasi bentuk bangun segiempat dan segitiga berdasarkan bentuk yang dilihat secara utuh serta sifat yang dimiliki. Hasil ini didukung dengan penelitian yang dilakukan oleh Yudianto, Nindya, \& Setiawan (2021) yang menyatakan bahwa pada tingkat visualisasi siswa hanya mengenal bentuk geometris berdasarkan ciri dan tampilan visual secara keseluruhan. Siswa reflektif juga mampu memberikan nama dengan benar pada bangun-bangun segiempat dan segitiga yang ditanyakan. Meskipun sempat terkecoh dengan menganggap trapesium sebagai jajar genjang, akan tetapi siswa reflektif mampu mengetahui letak kekeliruan dalam menjawab dengan mengingat kembali ciri dari trapesium maupun jajar genjang sehingga mendapatkan jawaban yang tepat. Hal ini sesuai dengan karakteristik siswa reflektif yang teliti dan penuh pertimbangan, sehingga mampu menganalisis kesalahan dalam menjawab soal (Desmita, 2009).

Pada tingkat berpikir geometri level analisis, siswa reflektif sudah cukup memahami tiaptiap sifat bangun datar yang diketahui, bukan hanya sekadar menghafal sifatnya secara teori namun mampu menunjukkan sifat yang dimaksud, seperti sisi sejajar dan sumbu simetri. Selain itu, siswa reflektif juga mampu menganalisis kesamaan sifat beberapa bangun datar yang disajikan. Hal ini sejalan dengan penelitian yang dilakukan oleh Intan, Sahara, \& Nurfauziah (2021) yang menayatakan bahwa siswa pada tahap analisis dapat memberikan sifat-sifat suatu bangun secara tertulis. Meskipun demikian, tidak semua sifat-sifat bangun datar dapat dikelompokkan, sehingga masih ada beberapa jawaban siswa yang belum lengkap. Hasil ini tidak sesuai dengan dengan karakteristik siswa reflektif yang memeriksa akurasi dan kelengkapan jawaban. Akan tetapi, hal ini 
bisa saja terjadi dikarenakan penguasaan materi geometri segiempat dan segitiga juga menjadi penentu kemampuan siswa dalam menjawab soal. Faktor penyebab kesulitan siswa dalam menjawab soal geometri Van Hiele disebabkan karena penguasaan mengenai konsep dan sifat-sifat segiempat yang masih kurang (Sholihah \& Afriansyah, 2017).

Pada tingkat berpikir geometri level deduksi informal, siswa reflektif belum mampu menyelesaikan soal-soal yang diberikan, siswa mengalami kesulitan dalam memahami pertanyaan maupun materi yang ditanyakan, terutama materi hubungan suatu bangun datar. Hasil ini sejalan dengan penelitian Aditya \& Musa (2016) yang menyatakan bahwa siswa kurang memahami hubungan antar bangun segiempat baik persamaan dan perbedaan suatu bangun segiempat. Adapun soal yang berkaitan dengan luas suatu bangun datar, siswa reflektif juga belum mampu menyelesaikan soal dengan baik. Siswa hanya menghafal rumus-rumus luas suatu bangun datar dan tidak memahami bagaimana menginterpretasikan rumus tersebut, terutama jika bangun datar tersebut merupakan gabungan dari beberapa bangun datar. pada umumnya dalam proses belajar siswa hanya menghafal rumus tanpa memahami konsep sehingga siswa kurang memahami asal rumus yang digunakan untuk menghitung luas bangun datar segiempat (Anwar, 2019).

Adapun tingkat berpikir deduksi (tingkat 3) dan tingkat berpikir rigor (tingkat 4) juga belum mampu dicapai siswa reflektif, kebanyakan siswa tidak menjawab soal-soal tingkat 3 dan tingkat 4 , hal ini dikarenakan siswa tidak memahami maksud soal maupun materi yang ditanyakan. Berdasarkan hasil wawancara, siswa menyatakan belum pernah mengerjakan soal yang seperti ini, siswa juga kesulitan dalam menjawab soal yang membutuhkan penjelasan ataupun alasan, siswa jarang diberikan soal-soal yang menganalisis sehingga merasa kebingungan jika dihadapkan dengan soal-soal tersebut. Paparan ini didukung dengan hasil penelitian Razak \& Sutrisno (2017) yang menjelaskan bahwa siswa tidak dapat memahami peran aksioma dan teorema serta tidak dapat membuktikan secara deduktif.

\section{Analisis Tingkat Berpikir Siswa dengan Gaya Kognitif Impulsif}

Pada tahap visualisasi (tingkat 0) siswa impulsif mampu mengidentifikasi bentuk bangun segiempat dan segitiga serta mampu memberikan nama pada bangun-bangun yang ditanyakan namun tidak secara lengkap. Beberapa siswa masih keliru dalam mengelompokkan maupun memberikan nama, seperti menganggap persegi sebagai kotak. Hal ini sesuai dengan karakteristik siswa impulsif yang kurang cermat dalam ketelitian sehingga jawaban siswa kurang tepat (Kagan, 1965). Meskipun demikian, mayoritas jawaban siswa impulsif benar, sehingga siswa impulsif mampu mencapai level visualisasi. Hasil ini sejalan dengan penelitian Petrus, Karmila, \& Riady (2017) yang memaparkan bahwa siswa mampu mengidentifikasi bangun berdasarkan bentuk, dan melihat bangun berdasarkan sifat yang dimiliki, seperti jumlah sisi suatu bangun segiempat. 
Pada tingkat berpikir geometri level analisis, siswa impulsif mampu menuliskan sifat-sifat suatu bangun geometri, tetapi belum mampu menganalisis kesamaan sifat yang dimiliki. Berdasarkan hasil wawancara, diketahui bahwa siswa impulsif menuliskan secara asal sifat-sifat suatu bangun karena disediakan beberapa sifat yang diketahui, akan tetapi jika diminta untuk menganalisis kesamaan sifat, siswa tidak memahami dengan baik sifat-sifat yang dimiliki oleh suatu bangun tersebut. Hal ini sesuai dengan karakteristik siswa impulsif yang cenderung merespon masalah dengan apa yang terlintas di pikiran tanpa memeriksa akurasi dan kelengkapan jawaban (Kagan, 1965). Hasil ini juga sejalan dengan penelitian Pertiwi \& Sudihartinih (2020) yang menjelaskan bahwa siswa masih kesulitan dalam menjawab soal level analisis, hal ini dikarenakan dibutuhkan ketelitian dan pemahaman materi yang cukup dalam.

Pada tingkat berpikir geometri level deduksi informal, siswa impulsif masih keliru dalam menentukan hubungan beberapa bangun datar. Kebanyakan siswa juga tidak menjawab soal sama sekali. Selain itu, dalam menjawab soal yang berkaitan dengan luas suatu bangun datar, siswa impulsif memahami maksud soal yang ditanyakan, namun siswa belum dapat menuliskan rumus yang tepat untuk menghitung luas suatu bangun. Siswa menuliskan secara langsung pada perhitungan sesuai dengan apa yang dipikirkan saat itu. Hal ini sesuai dengan karakteristik siswa impulsif yang cepat dalam membuat keputusan, merespon masalah tanpa pemeriksaan kritis, tidak sistematis dan terencana sehingga jawaban cenderung salah (Kagan, 1965). Paparan ini didukung oleh penelitian Sholihah \& Afriansyah (2017) yang memaparkan bahwa kesulitan siswa dalam proses pemecahan masalah geometri Van Hiele disebabkan karena siswa belum menguasai materi prasyarat yang belum kuat dan kurangnya keterampilan menggunakan ide-ide geometri.

Adapun tingkat berpikir deduksi (tingkat 3) dan rigor (tingkat 4) juga belum mampu dicapai oleh siswa impulsif. Tidak satupun dari siswa impulsif yang menjawab soal di tingkat deduksi dan rigor. Berdasarkan hasil wawancara, diketahui bahwa siswa impulsif tidak mengerti dengan pertanyaan maupun materi yang ditanyakan dalam soal. Kesulitan siswa impulsif juga dialami oleh siswa reflektif. Oleh karena itu dalam penelitan ini, diperoleh fakta bahwa siswa tidak dapat naik ke tingkat berpikir yang lebih tinggi, tanpa melewati tingkat yang lebih rendah. Fakta ini sejalan dengan hasil penelitian yang dilakukan oleh Ain, Baidowi, \& Hapipi (2020) yang menyatakan bahwa siswa yang gagal mencapai tingkat sebelumnya, maka juga akan gagal mencapai tingkat selanjutnya.

Berdasarkan uraian yang telah dipaparkan di atas, dapat disimpulkan bahwa tingkat berpikir geometri Van Hiele yang mampu dicapai siswa reflektif yaitu tingkat analisis (tingkat 1) sedangkan tingkat berpikir yang mampu dicapai siswa impulsif yaitu tingkat visualisasi (tingkat 0 ). Hal ini menunjukkan bahwa tingkat berpikir yang mampu dicapai siswa reflektif lebih tinggi dibandingkan siswa impulsif. Hasil ini juga sejalan dengan penelitian yang dilakukan oleh Nasriadi (2016) yang menyatakan bahwa siswa yang bergaya kognitif reflektif lebih baik dalam kemampuan berpikir geometri dibandingkan siswa impulsif. Meskipun demikian, baik siswa reflektif maupun siswa impulsif seharusnya mampu mencapai tingkat berpikir yang lebih tinggi, seperti tingkat deduksi 
informal (tingkat 2) dan tingkat deduksi (tingkat 3). Akan tetapi, dikarenakan kesulitan siswa dalam melakukan perhitungan, membuat kesimpulan dari proses perhitungan yang telah dilakukan, dan belum mampu dalam menyelidiki kebenaran hasil penyelesaian yang diperoleh.

Adapun tingkat berpikir rigor (tingkat 4) belum mampu dicapai siswa, dikarenakan pada tingkat berpikir rigor siswa harus mampu memahami betapa pentingnya ketepatan dari prinsipprinsip dasar yang melandasi suatu pembuktian. Siswa pada tingkat 4 (rigor/ketepatan) sudah memahami betapa pentingnya ketepatan dari prinsip-prinsip dasar yang melandasi suatu pembuktian. Tingkat berpikir rigor merupakan level tertinggi dalam memahami geometri sehingga pada tahap ini memerlukan tahap berpikir yang kompleks dan rumit. Biasanya tingkat berpikir rigor dicapai pada jenjang perguruan tinggi yang mempelajari geometri (Van de Walle, 2001:310).

Setelah proses pengumpulan data dan analisis data, ternyata diperoleh temuan bahwa 2 siswa slow inaccurate belum mampu mencapai tingkat visualisasi (tingkat 0), sehingga siswa tersebut dikelompokkan ke dalam tingkat pravisualisasi. Hal ini sesuai dengan kriteria pengelompokan tingkat berpikir Van Hiele, yaitu siswa yang tidak mencapai tingkat visualisasi, maka siswa diklasifikasikan ke dalam tingkat pravisualisasi (Usiskin, 1982:23). Siswa yang berada pada tingkat pravisualisasi belum mampu menentukan bentuk bangun segiempat dan segitiga. Siswa secara asal dalam menentukan kelompok bangun tersebut. Selain itu, siswa juga belum mampu memberikan nama pada bangun-bangun datar yang ditanyakan. Oleh karena itu, dapat dikatakan bahwa 2 siswa ini belum mampu mencapai tingkat berpikir visualisasi. Hasil ini sejalan dengan penelitian Ain, Baidowi, \& Hapipi (2020) yang memaparkan bahwa faktor ketidakmampuan siswa mencapai tahap berpikir visualisasi dikarenakan siswa keliru dalam menentukan nama dalam suatu bangun geometri.

Adapun soal-soal berikutnya juga tidak kerjakan oleh siswa slow inaccurate. Siswa menyatakan tidak mengerti dengan pertanyaan maupun materi yang ditanyakan. Lebih lanjut, pada saat mengerjakan soal siswa juga sudah berulang kali membaca soal, namun tidak dapat menjawab pertanyaan dengan baik. Hal ini sesuai dengan karakteristik siswa slow inaccurate yaitu lambat dalam menyelesaikan suatu masalah dengan kecendrungan jawaban yang diberikan juga belum tepat (Kagan \& Kogan, 1970). Informasi mengenai gaya kognitif dan tingkat berpikir yang mampu dicapai siswa dapat menjadi acuan bagi guru dalam melaksanakan pembelajaran. Pembelajaran geometri khususnya segiempat dan segitiga sangat penting untuk dipahami siswa, mengingat materi tersebut merupakan materi prasyarat untuk mempelajari bangun ruang. Guru harus mengetahui tingkat perkembangan mental anak dan bagaimana pembelajaran harus dilakukan sesuai dengan tahap-tahap perkembangan tersebut (Suherman, 2003:13).

\section{KESIMPULAN}

Berdasarkan hasil penelitian dan pembahasan yang dilakukan, maka diperoleh kesimpulan dalam penelitian ini, sebagai berikut: 
1. Tingkat berpikir siswa dengan gaya kognitif reflektif dalam menyelesaikan soal geometri materi segiempat dan segitiga berdasarkan teori Van Hiele berada pada tingkat analisis (tingkat 1). Adapun indikator yang mampu dicapai siswa reflektif yaitu, mampu mengidentifikasi bentuk bangun segiempat dan segitiga berdasarkan gambar yang dilihatnya secara utuh, mampu menentukan nama-nama suatu bangun segiempat dan segitiga, mampu menentukan sifat-sifat suatu bangun datar dan mampu menentukan kesamaan sifat dari beberapa bangun datar segiempat.

2. Tingkat berpikir siswa dengan gaya kognitif impulsif dalam menyelesaikan soal geometri materi segiempat dan segitiga berdasarkan teori Van Hiele berada pada tingkat visualisasi (tingkat 0). Adapun indikator yang mampu dicapai siswa impulsif yaitu, mampu mengidentifikasi bentuk bangun segiempat dan segitiga berdasarkan gambar yang dilihatnya secara utuh dan mampu menentukan nama-nama suatu bangun segiempat dan segitiga.

\section{UCAPAN TERIMA KASIH}

Penyusunan penelitian ini tidak terlepas dari doa, arahan, bimbingan, bantuan, dan peran serta berbagai pihak. Oleh karena itu, pada kesempatan ini penulis menyampaikan terima kasih kepada:

1. Dr. Laila Hayati, S.Pd., M.Si. selaku dosen pembimbing I, Nourma Pramestie Wulandari, S.Pd., M.Pd. selaku dosen pembimbing II, dan Syahrul Azmi, S.Pd., M.Pd. selaku dosen penguji.

2. Dr. H. Akhmad Zaenal Abidin, S.Pd., M.Pd. selaku kepala sekolah SMP Negeri Wanasaba yang telah memberikan izin melakukan penelitian, serta seluruh guru, karyawan, siswa kelas VIII-H yang telah membantu dan memberikan dukungan selama penelitian.

3. Teman-temanku yang telah bersedia membantu dalam melakukan penelitian (Kak Hayani S.Pd, Hirnani Julianti, Dinda Safitri, Rizka Azizaturrohmi, Arvinia Trisnindianti, Nurul Fitriani, Nurhidayatul Aini, Rizkia Apriani, Ni Nyoman Yustini Wikantari, dan Silma Safira Hifyatin.

\section{DAFTAR PUSTAKA}

Aditya, L., \& Musa, D. (2016). Level Berpikir Geometri Menurut Teori Van Hiele Berdasarkan Kemampuan Geometri dan Perbedaan Gender Siswa Kelas VII SMPN 8 Pare-pare. AlKhwarizmi: Jurnal Pendidikan Matematika Dan Ilmu Pengetahuan Alam, 4(2), 103-116.

Aiken, L. R. (1985). Three Coefficients for Analyzing The Reliability and Validity of Ratings. Educational and Psychological Measurement: SAGE Journals, 45(1), 131-142.

Ain, H., Baidowi, \& Hapipi. (2020). Kemampuan Siswa dalam Pemecahan Masalah Geometri Berdasarkan Tingkat Berpikir Van Hiele. Jurnal Pijar MIPA, 15(3), 273-279.

Anwar, A. (2019). Perbedaan Hasil Belajar Matematika Siswa Ditinjau dari Level Geometri Van Hiele SMP kelas VII. Mandalika Mathematics and Education Journal, 1(2), 74-80.

Azhil, I. M., Ernawati, A., \& Lutfianto, M. (2017). Profil Pemecahan Masalah Matematika Siswa Ditinjau dari Gaya Kognitif Reflektif dan Impulsif. Jurnal Review Pembelajaran Matematika, $2(1), 60-68$. 
Desmita. (2009). Psikologi Perkembangan Peserta Didik. Bandung: PT Remaja Rosdakarya.

Ilhamuddin, Ridwan, M., \& M, M. D. (2021). Deskripsi Pemahaman Konsep dalam Menyelesaikan Soal Teorema Phytagoras Ditinjau dari Gaya Kognitif pada Siswa Kelas VIII SMP Negeri 3 Camba. Infinity: Jurnal Matematika Dan Aplikasinya (IJMA), 2(1), 40-50.

Indah, N., Prayitno, S., Amrullah, \& Baidowi. (2021). Analisis Kemampuan Pemecahan Masalah Matematika pada Materi Pola Bilangan Ditinjau dari Gaya Kognitif Reflektif-Impulsif. Griya Journal of Mathematics Education and Application, 1(2), 106-114.

Intan, R., Sahara, A., \& Nurfauziah, P. (2021). Analisis Kesulitan Siswa Materi Bangun Ruang Sisi Datar Berdasarkan Tahap Berpikir Van Hiele. Jurnal Pembelajaran Matematika Inovatif, 4(4), 911-920.

Junaedi, B. (2017). Penerapan Teori Belajar Van Hiele pada Materi Geometri Di Kelas VIII. MES (Journal of Mathematics Education and Science), 3(1), 1-7.

Kagan, J. (1965). Impulsive and reflective children: Significance of conceptual tempo. Dalam Krumboltz, J.D (Eds.) Learning and the Educational Process, 1(1), 133-161.

Kagan, J., \& Kogan, N. (1970). Individual variation in cognitive process. Dalam Mussan, P. (Edt.) Carmichael's Manual of Child Psychology (3rd Ed. Vol. 1) Wiley New York., 1(1).

Mahfiroh, N., Mustangin, \& Wulandari, T. C. (2021). Kemampuan Pemecahan Masalah Matematis Ditinjau dari Gaya Kognitif. LAPLACE: Jurnal Pendidikan Matematika, 4(1), 63-74.

Moleong, L. J. (2014). Metodologi Penelitian Kualitatif. Bandung: PT Remaja Rosdakarya.

Nasriadi, A. (2016). Berpikir Reflektif Siswa SMP dalam Memecahkan Masalah Matematika Ditinjau dari Perbedaan Gaya Kognitif. E-Journal STKIP BBG, III(1), 15-26.

Pertiwi, M., \& Sudihartinih, E. (2020). Analisis Kemampuan Berpikir Geometri Van Hiele Siswa Sekolah Menengah Pertama Ditinjau dari Perspektif Gender. PYTHAGORAS: Jurnal Program Studi Pendidkan Matematika, 9(2), 86-94.

Petrus, Z., Karmila, \& Riady, A. (2017). Deskripsi Kemampuan Geometri Siswa SMP Berdasarkan Teori Van Hiele. Pedagogy: Jurnal Pendidikan Matematika, 2(1), 145-160.

Razak, F., \& Sutrisno, A. B. (2017). Analisis Tingkat Berpikir Siswa Berdasarkan Teori Van Hiele pada Materi Dimensi Tiga Ditinjau dari Gaya Kognitif Field Dependent. Edumatica, 07(02), 22 29.

Rozencwajg, P., \& Corroyer, D. (2005). Cognitive Processes In The Reflective - Impulsive Cognitive Style. The Journal of Genetic Psychology, 166(4), 451-463.

Sa'o, S., Naja, F. Y., \& Mei, A. (2020). Tingkat Berpikir Geometri Van Hiele Ditinjau dari Perbedaan Gender dan Kemampuan Matematika. Jurnal Dedikasi Pendidikan, 4(2), 171-182.

Saifuddin, A. (2020). Penyusunan Skala Psikologi. Jakarta: KENCANA.

Sholihah, S. Z., \& Afriansyah, E. A. (2017). Analisis Kesulitan Siswa dalam Proses Pemecahan Masalah Geometri Berdasarkan Tahapan Berpikir Van Hiele. Jurnal Mosharafa, 6(2), 287-298. 
Suherman, E. (2003). Strategi Pembelajaran Matematika Kontemporer. Bandung: Universitas Pendidikan Indonesia.

Usiskin, Z. (1982). Van Hiele Levels and Achievement In Secondary School Geometry. Chicago: The University of Chicago.

Van de Walle, J. A. (2001). Chapter 17 Geometric Thinking and Geometric Concepts. In Elementary and Middle School Mathematics: Teaching Developmentally (4th editio, pp. 306-312). Pearson Education.

Warli. (2013). Kreativitas Siswa SMP yang Bergaya Kognitif Reflektif atau Impulsif dalam Memecahkan Masalah Geometri. Jurnal Pendidikan Dan Pembelajaran, 20(2), 190-201.

Yudianto, E., Nindya, Y. S., \& Setiawan, T. B. (2021). Kecemasan Geometri Siswa dalam Menyelesaikan Masalah Bangun Ruang Sisi Datar Ditinjau dari Teori Van Hiele. Jurnal Cendikia: Jurnal Pendidikan Matematika, 05(02), 1102-1115.

How to cite : Nurhaolida., Hayati, L., Wulandari, N. P., \& Azmi, S., 2022. Analisis Tingkat Berpikir Siswa Berdasarkan Teori Van Hiele Materi Segi Empat dan Segitiga Ditinjau dari Gaya Kognitif. Jurnal Riset Pendidikan Matematika Jakarta. 4(1). 34-45. https://doi.org/10.21009/jrpmj.v4i1.23024

To link to this article: https://doi.org/10.21009/jrpmj.v4i1.23024 